NOTE

\title{
Oceanic larval life of La Réunion 'bichiques', amphidromous gobiid post-larvae
}

\author{
Thierry B. Hoareau ${ }^{1,2,3, *}$, Raymonde Lecomte-Finiger ${ }^{4}$, Henri-Paul Grondin ${ }^{2}$, \\ Chantal Conand ${ }^{1}$, Patrick Berrebi ${ }^{3,5}$ \\ ${ }^{1}$ Laboratoire d'Ecologie Marine, Université de La Réunion, 97715 Saint-Denis mes. Cedex 9, La Réunion, France \\ ${ }^{2}$ Association Réunionnaise pour le Développement de l'Aquaculture-Centre des Eaux Douces, BP 16, Z.I. Les Sables, \\ 97427 Etang-Salé, La Réunion, France \\ ${ }^{3}$ Laboratoire Ecosystèmes Lagunaires, UMR 5119, cc093, and ${ }^{5}$ Institut des Sciences de l'Evolution, UMR 5554, cc065, \\ Université de Montpellier 2, place Bataillon, 34095 Montpellier Cedex 05, France \\ ${ }^{4}$ Laboratoire Ecosystèmes Aquatiques Tropicaux et Méditerranéens, UMR 8046 EPHE-CNRS, Université de Perpignan, \\ 52 Avenue Paul Alduy, 66860 Perpignan Cedex, France
}

\begin{abstract}
The 2 amphidromous gobiids Sicyopterus lagocephalus and Cotylopus acutipinnis from La Réunion Island (Mascarene archipelago, south-western Indian Ocean) are heavily exploited by traditional fisheries during their river colonisation. Traits of their oceanic larval life were investigated to better understand the complex life cycle of these fishes. Age estimates were established using otolith increment counts and an alizarin complexon validation method. Larval duration was longer for the widespread $S$. lagocephalus (133 to 266 d; mean $199 \pm 33$ d) than for the endemic C. acutipinnis (78 to $150 \mathrm{~d}$; mean $101 \pm 14 \mathrm{~d}$ ), which reflects their distributional ranges. For both species, no correlation was established between age and size, suggesting a decrease in growth during the larval phase. From the back-calculated birth dates, all $S$. lagocephalus of a major colonisation episode (December 2002) were hatched during the cool season. All results are discussed in terms of the recruitment origins of $S$. lagocephalus and $C$. acutipinnis within the Mascarenes. Recognition of the differences in larval life traits is essential for proposing both management and conservation measures for each species.
\end{abstract}

KEY WORDS: Sicyopterus lagocephalus · Cotylopus acutipinnis · Goby-fry · Otolith microincrement · Age validation · Hatching date

\section{INTRODUCTION}

Fisheries for Sicydiinae goby late larvae/early juveniles are widespread in inter-tropical regions and are often substantial (Bell 1999). At La Réunion Island (Mascarene archipelago, south-western Indian Ocean), such gobies are called 'bichiques' and belong to the species Sicyopterus lagocephalus Pallas, 1770 and Cotylopus acutipinnis Guichenot, 1863 (Gobiidae: Sicydiinae). These amphidromous species are ex- ploited by traditional fisheries during the late-larval/ early-juvenile stages, when they enter the mouths of rivers.

Little is known of the biology and ecology of these species, but a recent decline in catches (Bell 1999) has generated renewed interest. The Sicydiinae gobies have an amphidromous life cycle, which is defined as a riverine adult stage, reproducing multiple times, and an oceanic larval stage (McDowall 1988); larvae then return to the river mouths for colonisation and recruit- 
ment processes. The population is considered here $a$ priori as a set of inhabitants of a given species in a given river system. With an amphidromous life cycle, the only way for neighbouring populations (different rivers of a given island) or distant populations (between islands) to exchange individuals is dispersal during the larval stage.

Knowing the age of larvae colonising a freshwater river is essential for understanding these larval exchanges. Following a report on the daily formation of micro-increments on otoliths from fish larvae (Pannella 1971), the duration of larval phase has repeatedly been studied in teleost fishes from various environments. Some chronological and chemical data are therefore available on fishes that use both freshwater and marine environments in their life cycle, but the literature is often restricted to temperate anadromous species (e.g. Salmo salar) or catadromous eel species (e.g. Anguilla anguilla). Most of the studies available on amphidromous Sicydiinae are restricted to Caribbean (Bell et al. 1995), Hawaiian (Radtke et al. 1988, 2001), or Taiwanese islands (Shen et al. 1998).

Sicyopterus lagocephalus and Cotylopus acutipinnis are abundant in all the principal rivers of the Mascarene Islands, i.e. Mauritius and La Réunion (Hoareau 2005). Yet, large interspecific differences have been observed in the distributions of the 2 species: C. acutipinnis is endemic to the Mascarene Islands (Keith et al. 2005b), whereas S. lagocephalus is widely distributed in the Indo-Pacific region, from the Australes Islands in the Central Pacific region to the Comoros archipelago in the western Indian Ocean (Watson et al. 2000, Keith et al. 2005a). Moreover, a recent study conducted on the population genetics of $S$. lagocephalus from the Mascarene Islands (Hoareau 2005) found no genetic di- vergence between the 2 islands (Mauritius and La Réunion), but a major and rapid disruption in the genetic organisation within populations (new non-rare alleles appearing from one year to another). These results suggested high allo-recruitment: colonisation of larvae from non-local populations to the Mascarene area.

In the present study, we compared marine larval duration, total body length and hatching date of Sicyopterus lagocephalus and Cotylopus acutipinnis from a major river colonisation event during the warm season of December 2002. After validation of the daily increment deposition, the goal was to compare the biological and ecological characteristics of the post-larvae of both species using the duration of the marine larval phase and the individual sizes. One of our objectives was to investigate the link between life-history traits and species range (endemic vs. ubiquitous) of the 2 species investigated.

\section{MATERIALS AND METHODS}

Specimens of Sicyopterus lagocephalus and Cotylopus acutipinnis were collected by fishermen using traditional hoop-nets at the mouth of the Saint Etienne River, on the south-west side of La Réunion Island (Fig. 1) during a new-moon period (December 2002). For comparison, additional S. lagocephalus were collected in September 2003 at the same site in a similar manner. At La Réunion Island, S. lagocephalus is generally more abundant than $C$. acutipinnis in the bichique catches, and fewer C. acutipinnis were collected despite attempts to obtain equal sample sizes.

Some post-larvae sampled in 2002 were preserved in $95 \%$ EtOH immediately after collection for DNA
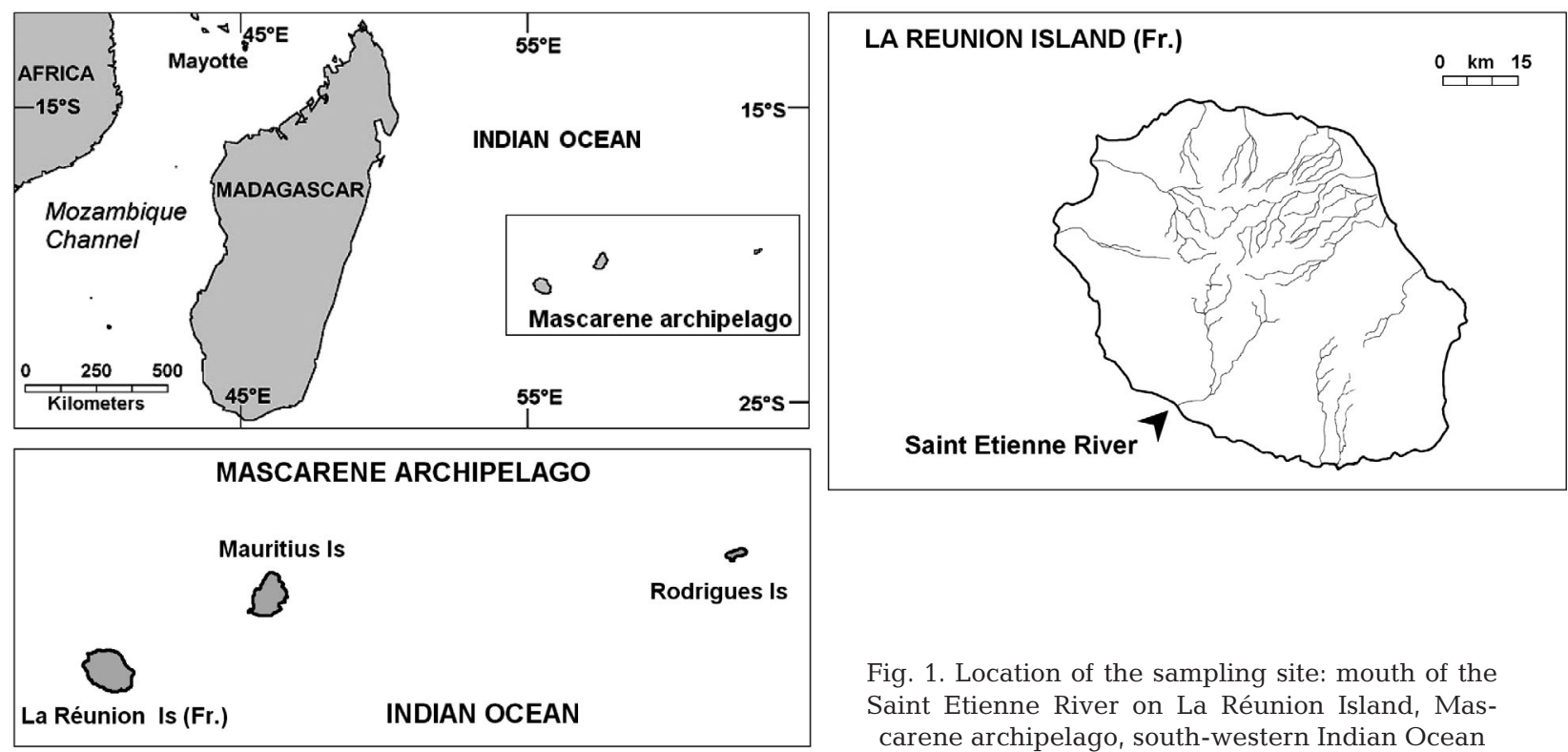

Fig. 1. Location of the sampling site: mouth of the Saint Etienne River on La Réunion Island, Mascarene archipelago, south-western Indian Ocean 
analysis, whereas others were maintained alive for the alizarin marking experiment. The total lengths (TL) of 130 preserved specimens of Sicyopterus lagocephalus and 32 preserved specimens of Cotylopus acutipinnis were measured to the nearest millimetre.

The daily basis of the increment deposition was verified using an alizarin validation method with Sicyopterus lagocephalus specimens. About 100 individuals of $S$. lagocephalus were brought alive to the laboratory, where they were acclimated in a $100 \mathrm{l}$ seawater tank with a sandy bottom. After $48 \mathrm{~h}$, they were immersed in an alizarin complexon solution $\left(30 \mathrm{mg} \mathrm{l}^{-1}\right)$ for $18 \mathrm{~h}$. All individuals were then transferred into a 1001 tank with clean water; 5 to 6 individuals were sacrificed after 9, 14, 17 and $23 \mathrm{~d}$. Otoliths were prepared for examination. Polished sections of 21 sagittae were viewed using the image capture system described below, and the alizarin ring was easily visible. The number of rings deposited after the alizarin ring were compared with the time since alizarin marking.

Otolith analyses were performed on a total of 81 specimens: Sicyopterus lagocephalus (33 in 2002 and 28 in 2003) and Cotylopus acutipinnis (20 in 2002). All sagittae were first embedded in Crystal-Bond, mounted on glass slides, and then ground and polished until the core was exposed on the sectioned surface using standard methods (Secor et al. 1992). Buffered Proteinase $\mathrm{K}$ was used to remove the protein matrix from the section surface and to enhance the contrast and visibility of increments as suggested by Shiao et al. (1999). An image of each sectioned sagitta was recorded using a phase-contrast light binocular microscope (OLYMPUS Cx41; 100×, 400×) and a digital camera (OLYMPUS Camedia C-5050 zoom, optical zoom $3 \times$ ). Internal otolith increments considered as daily growth rings were designated by dots on digital records and then counted using IMAGE J $1.27 \mathrm{z}$ (National Institute of Health, USA). The oceanic larval phase (in days) was recorded for each specimen, and the hatching date was back-calculated from the date of capture (31 December 2002). The core and the hatching check were distinct on all sagittal sections, and no recruitment check was observed on any of the sagittae examined for either species, confirming the recent oceanic origin of these individuals.

First increment formation was assumed to occur at hatching. Formation of otolith growth increments generally starts when the larvae develop an opening mouth (Panfili et al. 2002). After hatching, the free embryos of Sicyopterus lagocephalus, like other closed-mouth species, cannot spend more than $\sim 72 \mathrm{~h}$ in rivers, because early larval development starts in the sea (Bell \& Brown 1995). Because of the very short free-embryo period in rivers $(<3 \mathrm{~d})$, estimates of age and of the duration of oceanic larval phase were considered to be the same.

The mean $( \pm \mathrm{SD})$ age (in days) and size (total length in $\mathrm{mm}$ ) were calculated for each species. The mean total lengths of both species were compared by a Student's $t$-test, and their ages were compared using a Mann-Whitney $U$-test. The hatching date distributions are presented in classes of $30 \mathrm{~d}$, based on the months of the solar calendar. The size-at-colonisation distributions are presented in classes of $1 \mathrm{~mm}$. The relationships between otolith increment deposition and age, and between age and total body length, were determined using Pearson's $r$ correlation coefficient. All statistical tests were performed using STATISTICA v.5.5.

\section{RESULTS}

Daily deposition of increments on the sagittae of Sicyopterus lagocephalus was confirmed through a validation experiment. A clear fluorescent red mark was left on otoliths of fish immersed in alizarin complexon solution. The slope of the regression between known days from marking $(x)$ and number of increments $(y)$ was not significantly different from 1 ( $\mathrm{r}=$ $0.989, y=0.9693 x+0.5411, t=-0.00548, p=0.4978$, $\mathrm{N}=21$ ). These results support the use of otolith increments for determining the age of Sicydiinae gobies.

The post-larvae of Sicyopterus lagocephalus were significantly older and longer than the post-larvae of Cotylopus acutipinnis (Table 1). The age distribution of C. acutipinnis is clearly more restricted than the age distribution of S. lagocephalus from December 2002 (Fig. 2A). The age distribution of $S$. lagocephalus from September 2003 was similar to that from December $2002(U=389.5, \mathrm{p}=0.1464, \mathrm{~N}=63)$, suggesting that the ages reported here represent general patterns. There was no significant cForrelation between age and total length for either sample or species ( $S$. lagocephalus 2002, $\mathrm{r}=0.04, \mathrm{p}=0.83, \mathrm{~N}=33 ; 2003, \mathrm{r}=0.21$, $\mathrm{p}=0.28, \mathrm{~N}=28 ; C$. acutipinnis 2002, $\mathrm{r}=-0.53, \mathrm{p}=0.08$, $\mathrm{N}=20$ ) (Fig. 2B).

Table 1. Total age length and parameters (mean, standard error and sample size) for the 2 species studied, with statistical comparisons: Student's $t$-test and Mann-Whitney $U$-test

\begin{tabular}{|c|c|c|c|c|c|c|c|}
\hline \multirow[t]{2}{*}{ Parameter } & \multicolumn{3}{|c|}{$\begin{array}{c}\text { Sicyopterus } \\
\text { lagocephalus }\end{array}$} & \multicolumn{3}{|c|}{$\begin{array}{c}\text { Cotylopus } \\
\text { acutipinnis }\end{array}$} & \multirow[t]{2}{*}{ Statistical test } \\
\hline & Mean & SE & $\mathrm{N}$ & Mean & $\mathrm{SE}$ & $\mathrm{N}$ & \\
\hline Age (d) & 199 & 33 & 33 & 101 & 14 & 20 & $U=2.000 ; \quad \mathrm{p}<0.0001$ \\
\hline Length (mm) & 32.7 & 1.1 & 100 & 22.5 & 1.2 & 33 & $t=-8.168 ; \mathrm{p}<0.0001$ \\
\hline
\end{tabular}



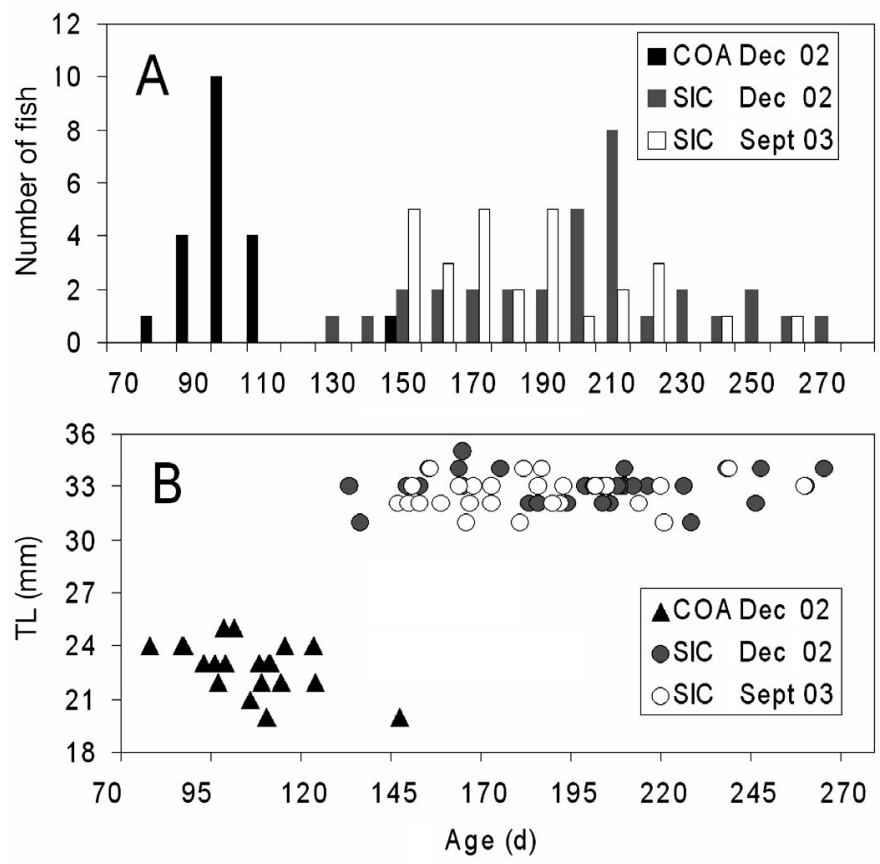

Fig. 2 (A) Age-frequency distribution of post-larvae of Sicyopterus lagocephalus (SIC; $\mathrm{N}=33$ in 2002 and $\mathrm{N}=28$ in 2003) and Cotylopus acutipinnis (COA; $\mathrm{N}=20)$. (B) Age-total length (TL) relationships of post-larvae of $S$. lagocephalus (SIC; N = 33 in 2002 in grey and $N=28$ in 2003 in white) and $C$. acutipinnis $\left(\mathrm{COA}_{;} \mathrm{N}=20\right)$

Hatching of Sicyopterus lagocephalus extended over 6 mo (April to September 2002, southern hemisphere cool season) even though larvae were collected in the warm season, during 1 colonisation event (December) from the more active fisheries period (October to January; Hoareau 2005). For the September 2003 colonisation event, the hatching dates of $S$. lagocephalus extended over 4 mo only, from January to April 2003. In contrast, the hatching period of Cotylopus acutipinnis encompassed 3 mo (August to October 2002).

\section{DISCUSSION}

\section{Oceanic larval life}

Recent reports have shown that marine species can have a limited distribution area, even though the larvae have the potential to disperse over long distances (Taylor \& Hellberg 2003): these studies refute the relation between the duration of the larval phase in fish and their distribution area. In this study, we demonstrate that Sicyopterus lagocephalus has a very long larval phase $(199 \pm 33 \mathrm{~d})$. This peculiarity could allow larvae to connect with remote populations, allowing the species to maintain gene flow throughout the
$18000 \mathrm{~km}$ wide Indo-Pacific area (Keith et al. 2005a). In contrast, the closely related species Cotylopus acutipinnis has a shorter larval phase $(101 \pm 14 \mathrm{~d})$ and a more restricted distribution: endemic to the Mascarene archipelago, a $300 \mathrm{~km}$ range (Keith et al. 2005b). Several studies of amphidromous gobiids, such as Sicydium spp., endemic to the Caribbean Sea (West Indies; Bell et al. 1995), and Lentipes concolor and Stenogobius hawaiensis, only present in the Hawaiian archipelago (Radtke et al. 1988, 2001), have estimated larval durations ranging between 50 and $150 \mathrm{~d}$. These species seem to be similar to $C$. acutipinnis according to the duration of their larval phase and the distribution area. Sicyopterus japonicus can be considered as an intermediate case, with a long larval phase (186 d; Shiao et al. 1999) and a moderately wide distribution of about 2000 km (north-west Pacific zone; Masuda et al. 1984). Within these closely related amphidromous species the differences in larval phase duration also coincide with differences in distribution ranges.

Sicyopterus lagocephalus shows a larger agefrequency distribution than Cotylopus acutipinnis (Fig. 2A), the age class of $C$. acutipinnis being distributed over a $40 \mathrm{~d}$ interval, whereas $150 \mathrm{~d}$ were observed for $S$. lagocephalus. In the literature no more than a $60 \mathrm{~d}$ interval has been recorded within a colonisation episode for other amphidromous gobies (Radtke et al. 1988, 2001, Bell et al. 1995). To understand these results illustrating divergences in dispersal duration, both autochthonous (local) and allochthonous (remote) origins of $S$. lagocephalus post-larvae entering the mouths of rivers can be postulated.

Our results also show that the larval phase is longer in amphidromous fishes than in fully marine demersal fishes (20 to 90 d) (Brothers et al. 1983, Victor 1986). A greater habitat fragmentation among Sicydiinae could explain this difference compared to marine species. Within tropical eel species showing the same highly fragmented habitat, wide-scale dispersal has been observed (Arai et al. 2000, Shiao et al. 2002). The larval phase duration and growth rate are important factors affecting the dispersion, the segregation between closely related species and their distribution area (Arai et al. 2000, Shiao et al. 2002). These larval traits probably affect the dispersion of Sicyopterus lagocephalus and Cotylopus acutipinnis and may explain most of the differences in their distribution area.

Hatching occurs during the cool season for Sicyopterus lagocephalus and at the beginning of warm season for Cotylopus acutipinnis (Fig. 3). As our sampling took place during the peak of the fishery season (December), the more active reproduction period seems to occur during the cool season for S. lagocephalus. No conclusions can be drawn for C. acutipinnis, because of its low frequency in bichique samples. 


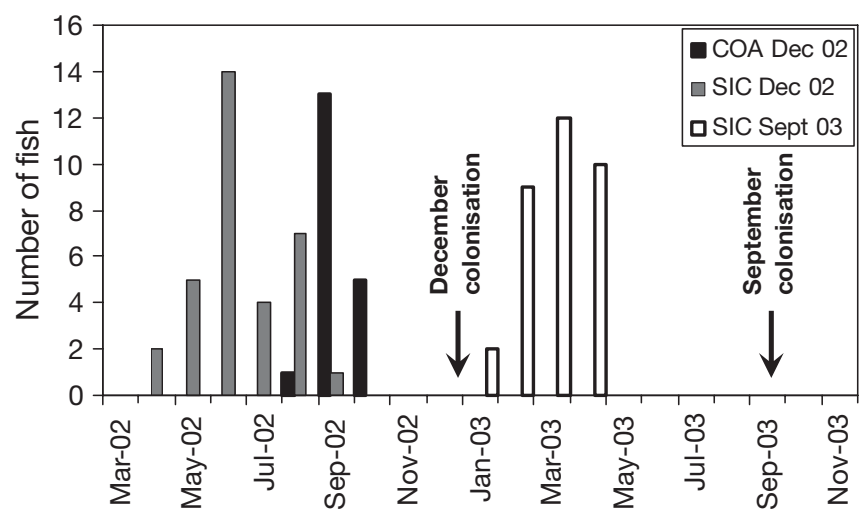

Fig. 3. Frequency distribution of the hatching date of postlarvae of Sicyopterus lagocephalus ( $\mathrm{SIC}_{i} \mathrm{~N}=33$ ) and Cotylopus acutipinnis $\left(\mathrm{COA}_{;} \mathrm{N}=20\right)$ at new moon in December 2002 and $S$. lagocephalus ( $\mathrm{SIC}_{;} \mathrm{N}=28$ ) at new moon in September

\section{Size at colonisation}

Major differences in size have been observed between both species; the total length ranged from 20 to $25 \mathrm{~mm}$ for Cotylopus acutipinnis and from 30 to $36 \mathrm{~mm}$ for Sicyopterus lagocephalus (Fig. 4). These differences in relation to age suggest that $C$. acutipinnis exhibits lower mean growth than $S$. lagocephalus (Fig. 2B). Some differences among S. lagocephalus have been recorded in the size at colonisation between regions. An inventory of the Mayotte Rivers, Comoros Island (Hoareau et al. unpubl. data from 2004), included the presence of several translucent specimens of S. lagocephalus (post-larvae) of about $28 \mathrm{~mm}$ TL. Moreover, the various total lengths reported for $S$. extraneus, a synonym for $S$. lagocephalus from the Philippines (Watson et al. 2000), were smaller (22 to $32 \mathrm{~mm}, 25.9 \pm 0.7 \mathrm{~mm}$; Manacop 1953; Fig. 4). These differences in size between regions suggest at least 2 hypotheses: (1) a divergence of growth patterns between specimens from the different regions and/or (2) a high divergence in the duration of the larval phase between regions. Consequently, the recruits of La Réunion grow faster and/or experienced longer dispersal, suggesting remote origins.

Using post-larvae, significant and positive correlations have been shown between the size and age of amphidromous gobies in the West Indies (Sicydium spp.; Bell et al. 1995) and in Hawaii (Lentipes concolor; Radtke et al. 2001). In our results, the absence of any correlation for both species (Fig. 2B) was observed in 2002 and confirmed in the Sicyopterus lagocephalus sample from September 2003, showing that this feature is consistent. Different hypotheses could explain these results: (1) differences in individual growth rates could depend on the environmental conditions during dispersal, (2) the growth rate could slow down during dispersal and/or (3) a size threshold could signal migration to the river. A decline in the growth rate during the planktonic phase has already been shown for marine fish with long larval phases (Victor 1986). This decrease in growth could be due to reallocation of resources between swimming activity (movement and feeding) and growth following the extended larval phase. This larval life trait could allow the development of a latent phase during the planktonic stage that would increase the chance of detecting river mouths.

\section{Autochthonous vs. allochthonous origins}

The specimens of Cotylopus acutipinnis captured are assumed to have hatched in rivers of the Mascarene archipelago, because of its endemism. With their extended larval life (about $100 \mathrm{~d}$ ), the C. acutipinnis larvae from the 2 islands (separated by about $200 \mathrm{~km}$ ) are probably well mixed before they return to the rivers. This is suggested by previous genetic analyses showing that all inhabitants of both islands belong to the same population (Hoareau 2005). Sicyopterus lagocephalus is distributed throughout the Indo-Pacific region (Watson et al. 2000, Keith et al. 2005a), suggesting regular connectivity between neighbouring populations. The presence of autochthonous and allochthonous specimens of $S$. lagocephalus in La Réunion rivers is likely and has already been suggested by Berrebi et al. (2005). This would result in the mixing of several genetically distinct populations from its wide metapopulation, which would not be the case for endemic species with homogeneous populations (Hoareau 2005).

Several observations suggest the presence of allochthonous Sicyopterus lagocephalus at La Réunion. (1) The larval phase of $S$. lagocephalus is twice as long as that of the sympatric endemic species Cotylopus acutip-

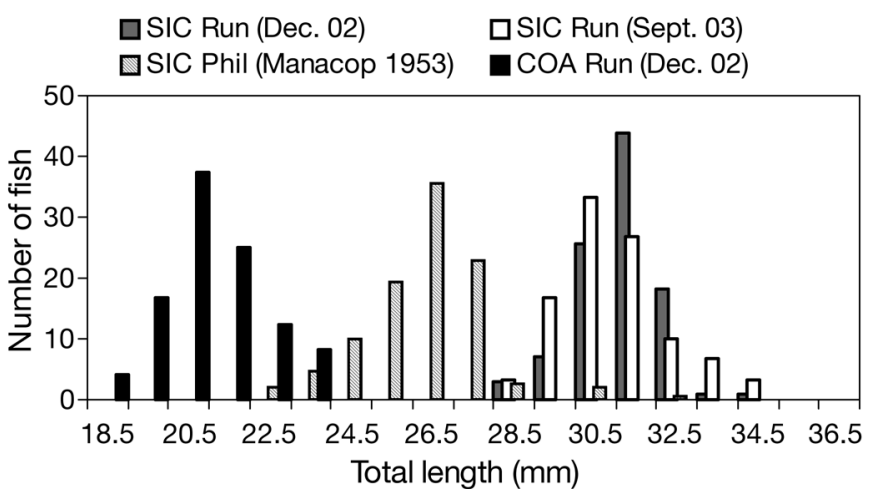

Fig. 4. Total length-frequency distribution of the post-larvae of Sicyopterus lagocephalus from La Réunion (SIC Run [Dec. 02], $\mathrm{N}=100$ and SIC Run [Sept. 03], N = 30) and Philippines (SIC Phil. [Manacop 1953]; $\mathrm{N}=300$ ) and Cotylopus acutipinnis from $\mathrm{La}$ Réunion (COA Run [Dec. 02]; $\mathrm{N}=32$ ) during the new moon period 
innis, suggesting higher dispersal for the widespread species. (2) The $S$. lagocephalus age range is wider than that of the other studied Sicydiinae. This suggests the mixing of larvae that experienced different dispersal routes, possibly due to multiple origins. (3) The size of $S$. lagocephalus is larger at La Réunion than in other regions studied, suggesting the greater larval dispersal to La Réunion and a more remote origin of recruits. (4) The results suggest a decrease in growth during the planktonic phase. These observations are in agreement with results obtained in previous genetic studies on $S$. lagocephalus in La Réunion and Mauritius rivers, where at least 2 sub-groups have been detected in each river (Berrebi et al. 2005, Hoareau 2005). In the aforementioned studies, the most probable hypothesis was a Wahlund effect, appearing to favour the colonisation of allochthonous specimens. The open population paradigm can be proposed here for the ecological scale and not only for the evolutionary and zoogeographic scales, as suggested by Leis (2002) for marine demersal fish.

The very long larval phase of Sicyopterus lagocephalus and, more generally, of the amphidromous gobiids can be considered a genetic adaptation permitting these species to increase the time required to detect the fragmented adult freshwater environments using oceanic currents. Thus, the duration of the larval phase is one of the crucial factors influencing the dispersal process and the distribution range of this group. The particular larval traits of each species demand further investigations to provide management tools for the widespread $S$. lagocephalus and a conservation programme for the endemic Cotylopus acutipinnis.

Acknowledgements. We are grateful to all the fishermen from Saint Etienne River for their assistance during the field study. We thank J. Morin, G. Cattaneo-Berrebi, T. Meldgaard and E. Boissin for their valuable technical help in the laboratory. We thank R. Britton for linguistic help and the anonymous reviewers for comments and constructive advice. This work is part of T. B. Hoareau's PhD thesis and was financially supported in part by the La Réunion Region.

\section{LITERATURE CITED}

Arai T, Otake T, Tsukamoto K (2000) Timing of metamorphosis and larval segregation of the Atlantic eels A. anguilla and $A$. rostrata as revealed by otolith microstructure and microchemistry. Mar Biol 137:39-45

Bell KNI (1999) An overview of goby-fry fisheries. Naga 22: 30-36

Bell KNI, Brown JA (1995) Active salinity choice and enhanced swimming endurance in 0 to 8 -d-old larvae of diadromous gobies, with emphasis on Sicydium punctatum (Pisces), in Dominica, West Indies. Mar Biol 121:409-417

Bell KNI, Pepin P, Brown JA (1995) Seasonal, inverse cycling of length and age at recruitment in the diadromous gobies Sicydium punctatum and Sicydium antillarum in Dominica, West Indies. Can J Fish Aquat Sci 52:1535-1545

Berrebi P, Cattaneo-Berrebi G, Valade P, Ricou JF, Hoareau T
(2005) Genetic homogeneity in eight freshwater populations of Sicyopterus lagocephalus, an amphidromous gobiid of La Réunion island. Mar Biol 148:179-188

Brothers EB, Williams D, Sale PF (1983) Length of larval life in twelve families of fish at 'One Tree Lagoon ', Great Barrier Reef, Australia. Mar Biol 76:319-324

Hoareau T (2005) Structural dynamics of bichiques (S. lagocephalus), amphidromous gobiids of La Réunion Rivers. $\mathrm{PhD}$ thesis, University of La Réunion

Keith P, Galewski T, Cattaneo-Berrebi G, Hoareau T, Berrebi P (2005a) Ubiquity of Sicyopterus lagocephalus (Teleostei: Gobioidei) and phylogeography of the genus Sicyopterus in the Indo-Pacific area inferred from mitochondrial cytochrome $b$ gene. Mol Phylogenet Evol 37(3):721-732

Keith P, Hoareau T, Bosc P (2005b) The genus Cotylopus (Teleostei: Gobioidei) endemic to the rivers of islands of the Indian Ocean with description of a new species from Mayotte (Comoros). J Nat Hist 39(17):1395-1405

Leis JM (2002) Pacific coral-reef fishes: the implications of behaviour and ecology of larvae for biodiversity and conservation, and a reassessment of the open population paradigm. Environ Biol Fish 65(2):199-208

Manacop PR (1953) The life history and habits of the goby, Sicyopterus extraneus Herre (Anga) Gobiidae, with an account of the goby fry fishery of Cagayan River, Oriental Misamis. Philipp J Sci 2:1-60

Masuda H, Amaoka K, Araga C, Uyeno T, Yoshino T (1984) The fishes of the Japanese Archipelago, Vol 1. Tokai University Press, Tokyo

McDowall RM (1988) Diadromy in fishes: migrations between freshwater and marine environments. Croom-Helm, London

Panfili J, de Pontual H, Troadec H, Wright PJ (2002) Manuel de sclérochronologie des poissons, Vol 1. Co-édition Ifremer-IRD, Brest

Pannella G (1971) Fish otoliths: daily growth layers and periodical patterns. Science 173:1124-1127

Radtke RL, Kinzie III RA, Folsom SD (1988) Age at recruitment of Hawaiian freshwater gobies. Environ Biol Fish 23: 205-213

Radtke RL, Kinzie III RA, Shafer DJ (2001) Temporal and spatial variation in length of larval life and size at settlement of the Hawaiian amphidromous goby Lentipes concolor. J Fish Biol 59:928-938

Secor DH, Dean JM, Laban EH (1992) Otolith removal and preparation for microstructural examination. In: Stevenson DK, Campana SE (eds) Otolith microstructure examination and analysis. Can Spec Publ Fish Aquat Sci 117:19-57

Shen KN, Lee YC, Tzeng WN (1998) Use of otolith microchemistry to investigate the life history pattern of gobies in a Taiwanese stream. Zool Stud 37:322-329

Shiao JC, Tzeng CS, Leu CL, Chen FC (1999) Enhancing the contrast and visibility of daily growth increments in fish otoliths etched by proteinase K buffer. J Fish Biol 54(2): 302-309

Shiao JC, Tzeng WN, Collins A, Iizuka Y (2002) Role of marine larval duration and growth rate of glass eels in determining the distribution of $A$. reinhardtii and A. australis on Australian eastern coasts. Mar Freshw Res 53:687-695

Taylor MS, Hellberg ME (2003) Genetic evidence for local retention of pelagic larvae in a Caribbean reef fish. Science 299:107-109

Victor BC (1986) Duration of the planktonic larval stage of one hundred species of Pacific and Atlantic wrasses (family Labridae). Mar Biol 90:317-326

Watson RE, Marquet G, Pöllabauer C (2000) New Caledonia fish species of the genus Sicyopterus (Teleostei: Gobiodei: Sicydiinae). Aqua J Ichthyol Aquat Biol 4(1):5-34 